\title{
Relações dialógicas e produção de sentidos: análise do anúncio publicitário da Femaçã 2015
}

\author{
DIALOGICAL RELATIONS AND PRODUCTION OF MEANING: \\ ANALYSIS OF THE FEMAÇÃ 2015 ADVERTISEMENT
}

\section{Luciana Maria Crestani Josiane Boff}

Universidade de Passo Fundo - UPF - Passo Fundo - Rio Grande do Sul - Brasil

Resumo: Com base, principalmente, nas proposições de Bakhtin (2003) acerca das relações dialógicas entre enunciados, este trabalho realiza a análise de um anúncio publicitário da "Femaçã 2015", tradicionalmente realizada em Veranópolis (RS). Tratase de uma peça publicitária que causou estranhamento ao público pelos discursos subjacentes que o arranjo da propaganda evoca. Nesse sentido, a análise buscou identificar os discursos evocados bem como os elementos que, na materialidade do anúncio, remetem a tais discursos, estabelecendo as relações dialógicas.

Palavras-chave: Anúncio publicitário. Relações dialógicas. Sincretismo de linguagens.

Abstract: Based especially on the propositions by Bakhtin (2003) on dialogical relations among statements, this work analyzes an advertisement of "Femaçã 2015", a feast traditionally held in the city of Veranópolis, RS, Brazil. It is a piece of advertisement that was frowned upon by the public because of the underlying speech its arrangement recalls. Hence, the analysis sought to identify the speeches conjured, as well as the elements that, in the materiality of the subject, refer to such speeches, thus establishing the dialogical relations.

Keywords: Advertisement. Dialogical relations. Languages syncretism. 


\section{Introdução}

No trabalho ora em foco, propõe-se a análise de um anúncio publicitário utilizado para a divulgação da 9a Festa Nacional da Maça e Feira Agroindustrial Femaçã 2015, evento tradicionalmente realizado na cidade de Veranópolis, localizada na Serra Gaúcha. Trata-se de um anúncio que causou estranhamento aos leitores e suscitou respostas polêmicas relacionadas à sua constituição enunciativa.

Como se sabe, o objetivo primeiro desses anúncios é divulgar - e vender - um produto, ou um serviço e, para tanto, as peças publicitárias aliam, em sua composição, estratégias verbais e não verbais que buscam despertar a atenção do leitor/consumidor para persuadi-lo a adquirir o que é ofertado. Esses arranjos constituem o que, à luz da semiótica greimasiana, costuma-se chamar de enunciados/textos ${ }^{1}$ sincréticos, em que diferentes grandezas semióticas atuam na construção dos sentidos. Entretanto, o sentido de um texto não está relacionado apenas ao conteúdo representado explicitamente, ou seja, àquilo que está materializado na superfície textual. Dado o caráter dialógico dos enunciados, o sentido destes está sempre atrelado a outros discursos que, cristalizados na memória, são evocados no momento da produção e/ou da recepção e interferem diretamente na atitude responsiva do leitor.

Nesse contexto, buscamos compreender as razões pelas quais a peça publicitária causou tal estranhamento aos leitores. Mais especificamente, buscamos, através da análise, identificar os discursos evocados e os elementos que, na materialidade do anúncio, remetem a tais discursos. Para tanto, inicialmente, à luz das proposições de Bakhtin (2003), revisitamos o conceito de enunciado, explicando o caráter responsivo e as relações dialógicas que o constituem. Num segundo momento, com base numa das teorias do texto e do discurso - a semiótica greimasiana $^{2}$-, abordamos o conceito de texto sincrético e apontamos características do gênero

\footnotetext{
1 Neste estudo, tomamos "texto" como sinônimo de "enunciado". Os motivos da adoção de tais terminologias como sinônimas estão justificados na seção 1 deste trabalho.
}

anúncio publicitário. Por fim, procedemos à análise do corpus: o anúncio utilizado para a divulgação da Femaçã 2015.

\section{Enunciado/texto e relação dialógicas}

Todas as atividades humanas, por mais variadas que sejam, estão relacionadas à utilização língua, efetuando-se em forma de enunciados, sejam eles orais ou escritos. Assim, em cada esfera discursiva (familiar, religiosa, jurídica, artística, empresarial, científica etc.), produzem-se enunciados mais os menos estáveis, os quais dão origem aos gêneros discursivos. Como explica Bakhtin (2003, p.262, grifos do autor), "[...] cada esfera de utilização da língua elabora seus tipos relativamente estáveis de enunciados, sendo isso que denominamos gêneros do discurso". Os gêneros do discurso, materializados em forma de enunciados, refletem as condições específicas e as finalidades do campo discursivo a que pertencem "não só por seu conteúdo (temático) e pelo estilo de linguagem [...] mas, acima de tudo, por sua construção composicional' (BAKHTIN, 2003, p. 261, grifos nosso). São esses os três elementos fundamentais que permitem reconhecer um enunciado e identificar o domínio discursivo a que ele pertence.

Os enunciados são tomados como as "reais unidades" da comunicação discursiva, uma vez que "o discurso só pode existir de fato na forma de enunciações concretas de determinados falantes, sujeitos do discurso. O discurso sempre está fundido em forma de enunciado pertencente a um determinado sujeito do discurso, e fora dessa forma não pode existir" (BAKHTIN, 2003, p. 274). Nesse sentido, de forma bastante simplificada, podemos conceber discurso como ideias, correntes de pensamentos relacionadas a um determinado campo discursivo, que só dão a conhecer quando enunciadas. Ou seja, surge um enunciado quando um sujeito se "apropria" de um discurso e o enuncia sob seu ponto de vista. Para Bakhtin (2003), o enunciado é "uma postura de

\footnotetext{
2 Para um estudo básico da Semiótica Greimasiana, vejam-se Fiorin (2000) e Barros (2000).
} 
sentido", que apresenta como características principais: constituir um todo de sentido, ser marcado por algum acabamento, ser passível de réplica (caráter responsivo dos enunciados) e ter natureza dialógica.

A natureza dialógica está relacionada ao sentido dos enunciados, ao que já foi e ao que será dito sobre determinado tema. Decorre do fato de que qualquer enunciado dialoga com outros enunciados que o antecederam e que o sucederão na linha do tempo, num contínuo processo responsivo de recriação e transformação do que já foi dito/escrito/representado de alguma forma. Nas palavras do teórico russo,

Cada enunciado isolado é um elo na cadeia da comunicação discursiva. [...] $\mathrm{O}$ objeto do discurso do falante, seja esse objeto qual for, não se torna pela primeira vez objeto do discurso em um dado enunciado, e um dado falante não é o primeiro a falar sobre ele. 0 objeto, por assim dizer, já está ressalvado, contestado, elucidado e avaliado de diferentes modos; nele se cruzam, convergem e divergem diferentes pontos de vista, visões de mundo, correntes (BAKHTIN, 2003, p. 299-300).

Assim, todo enunciado é uma resposta que desperta novas respostas. A responsividade implica uma compreensão ativa do que foi dito e um juízo de valor, que se estabelece embasado em outros discursos internalizados. Ao abordar a diferença entre unidades da língua (palavras e orações) e unidades do discurso (enunciados), Bakhtin (2003, p. 332) explica que "um enunciado pleno já não é uma unidade da língua [...] mas uma unidade da comunicação discursiva, que não tem significado mas sentido. (Isto é, um sentido pleno relacionado com o valor - com a verdade, a beleza, etc. - e que requer uma compreensão responsiva que inclui em si o juízo de valor)". Ou seja, o juízo de valor está imbricado na compreensão responsiva e determina o teor das respostas.

Ainda Bakhtin (2003, p. 331) acrescenta que: "dois enunciados distantes um do outro, tanto no

\footnotetext{
3 Authier-Revuz (1982) chama esta relação de heterogeneidade constitutiva; Koch (1991) a define como intertextualidade em sentido amplo.

4 O termo intertextualidade não aparece nos estudos bakhtinianos. Ele foi atribuído a Bakhtin por Julia Kristeva, que, em 1967, ao apresentar trabalho sobre Bakhtin, usou o termo
}

tempo quanto no espaço, que nada sabem um sobre o outro, no confronto dos sentidos revelam relações dialógicas se entre eles há ao menos alguma convergência de sentidos (ainda que seja uma identidade particular do tema, do ponto de vista, etc)". Assim, mesmo que não tenhamos conhecimento de outros enunciados com os quais os nossos se relacionam, o dialogismo se faz presente se há algum elo de ligação entre eles, independentemente da relação estabelecida (de complementação, de recusa, de aceitação, de divergência, etc.). A esse tipo de dialogismo implícito, "que não se mostra no fio do discurso" (FIORIN, 2006a, p. 32), chamamos dialogismo constitutivo ${ }^{3}$, ou interdiscurso.

No entanto, há formas explícitas de dialogismo que remetem diretamente a determinados enunciados anteriores. A isso Bakhtin (2003) denomina concepção estreita de dialogismo. "Trata-se da incorporação pelo enunciador da voz ou das vozes de outro(s) no enunciado. Nesse caso, o dialogismo é uma forma composicional. São maneiras externas e visíveis de mostrar outras vozes no discurso" (FIORIN, 2006a, p. 32). É o caso, por exemplo, da utilização de aspas, da estilização, da paródia, etc. Nesses casos, o enunciador determina e mostra o enunciado com o qual o seu dialoga por meio de marcas materiais que remetem àquele.

Dado o desdobramento das vertentes teóricas que se apoiam no estudo dos gêneros discursivos proposto em Bakhtin, o termo dialogismo, em algumas delas, é tomado como sinônimo de "intertextualidade"4. No entanto, Fiorin (2006a, p. 52) lembra que o enunciado é da ordem do sentido, "é uma posição assumida por um enunciador", e o texto é da ordem da manifestação, "é uma realidade imediata, dotada de materialidade, que advém de ser um conjunto de signos" (FIORIN, 2006a, p. 52). Então, "intertextualidade deveria ser a denominação de um tipo de composicional de dialogismo: aquele em que há no interior do texto 0 encontro de duas

intertextualidade como sinônimo de dialogismo. Desde então, tal uso se difundiu. Barthes (1974), Koch (1991), Koch e Elias (2011) e Marcuschi (2008) são alguns autores que utilizam o termo "intertextualidade" para designar tanto as relações marcadas como as não marcadas na materialidade dos textos. 
materialidades lingüísticas, de dois textos. Para que isso ocorra é preciso que um texto tenha existência independente do texto com que ele dialoga". Já "quando um texto não mostra, no seu fio, o discurso de outro, não há intertextualidade, mas há interdiscursividade". (FIORIN, 2006a, p. 52-53). Assim, segundo Fiorin (2006a), toda intertextualidade implica existência de interdiscursividade, mas nem toda interdiscursividade implica uma intertextualidade.

No capítulo O problema do texto na lingüística, na filologia e em outras ciências humanas, ao mencionar características do texto, Bakhtin (2003) atribui a estes traços do enunciado, explicando que 0 texto pode se tornar enunciado quando o que se leva em conta nele (no texto) é o seu sentido dialógico e não a sua materialidade apenas, ou seja, quando o que importa são as relações dialógicas que se estabelecem entre textos e não as relações de ordem estrutural da língua ali manifestas. Fiorin (2006b, p.180) assim explica tal questão:

$\mathrm{Na}$ medida em que um texto se torna enunciado, ele é distinto deste. O texto pode ser visto como enunciado, mas pode não o ser, pois quando o enunciado é considerado fora da relação dialógica, ele só tem realidade como texto. Pode-se ter uma Lingüística que estuda o texto, mas o faz como uma entidade em si, fora das relações dialógicas, já que essas não podem ser objeto da Lingüística.

Para Bakhtin (2003, p.309), então, o texto é concebido como enunciado quando "incluído na comunicação discursiva (na cadeia textológica) de dado campo". Sob esse prisma, neste trabalho tomamos "texto" como sinônimo de "enunciado", uma vez que o objetivo principal é abordar as relações dialógicas (interdiscursivas e intertextuais) que se estabelecem a partir do conteúdo veiculado no anúncio publicitário objeto de análise.

Também é válido mencionar que o conteúdo (sentido) de um enunciado pode ser expresso "por qualquer conjunto coerente de signos, seja qual for sua forma de expressão (pictórica, gestual, etc.) " (FIORIN, 2006a, p. 52). É o que ocorre no texto objeto de estudo, em que o sentido se materializa por diferentes formas de expressão (verbal e não-verbal), constituindo o que, na perspectiva da semiótica greimasiana, chama-se texto sincrético.

\section{3 o "anúncio publicitário" e o sincretismo de linguagens}

$\mathrm{Na}$ grande relação de trocas comunicativas entre os seres humanos, encontram-se os gêneros discursivos do domínio publicitário. Esses se materializam em forma de textos (gêneros textuais) que, de acordo com suas particularidades, assumem estruturas composicionais diferenciadas e recebem diferentes denominações ${ }^{5}$ panfletos comerciais, encartes de jornais, anúncios de rádio, comerciais de TV, anúncios classificados, etc. No entanto, como explica Bahtia (2001, p.105), "as diferenças entre esses gêneros são pouco discerníveis em termos de propósitos comunicativos e mais em termos do meio de discurso e portanto pertencem, como gêneros, à mesma categoria geral popularmente conhecida como anúncios". Nesse sentido, utilizamos a expressão "anúncio publicitário" para nomear o gênero textual que constitui nosso corpus de análise.

As características deste tipo de anúncio publicitário (em termos de conteúdo temático, construção composicional e estilo) não nos são estranhas, pois, como explica Bakhtin, "os gêneros do discurso são modelos tipológicos de construção da totalidade discursiva" (2003, p.334), ou "tipos relativamente estáveis de enunciados" (2003, p. 262) que nos são dados tal como nos é dada a língua materna e que, desde muito cedo, aprendemos a reconhecer.

Esses anúncios possuem sempre o mesmo propósito: divulgar (e vender) produtos e/ou serviços. Buscam convencer o público de que algum produto ou serviço lhe é necessário, mesmo que, muitas vezes, não o seja. A intenção é persuadir o outro a adquirir algo. Para tanto, na sua composição enunciativa,

\footnotetext{
5 As denominações dos gêneros textuais nem sempre são consensuais e também nem sempre há, para cada gênero, uma denominação específica.
} 
utilizam-se estratégias de ordem diversificada. Uma das mais comuns é o emprego conjunto de elementos verbais e não verbais (imagens, cores, sons e movimentos - quando o suporte assim permite) que, aliados, formam um todo de sentido, um enunciado único.

Textos dessa natureza, como já se disse, são denominados pela semiótica greimasiana textos/enunciados sincréticos. Essa teoria postula que um texto é o resultado da união de um plano de conteúdo com um plano de expressão, do que surge o plano da manifestação, ou seja, a materialidade do texto. Assim, um mesmo plano de conteúdo pode ser materializado por diferentes planos de expressão. $O$ conteúdo de um livro, por exemplo, pode vir expresso também em forma de filme, ou de uma peça teatral. A teoria semiótica se interessa por textos verbais (como um romance, uma poesia, um editorial de jornal, etc.), visuais (uma gravura, uma aquarela, uma dança, etc.) ou sincréticos (um filme, uma história em quadrinhos, etc.) e procura "descrever e explicar o que o texto diz e como ele faz para dizer o que diz". (BARROS, 2000, p.7).

Greimas e Courtés (2008, p. 467) definem como sincréticas as semióticas "que - como a ópera ou o cinema - acionam várias linguagens de manifestação; da mesma forma, a comunicação verbal não é somente de tipo linguístico: inclui igualmente elementos paralinguísticos (como a gestualidade ou a proxêmica), sociolinguísticos, etc." Esses elementos são significativos na composição do enunciado, pois agregam "informações" não expressas pelo verbal mas importantes para a construção do todo de sentido. Para Barros (1986, p. 36), "o sincretismo semiótico define-se como sendo o resultado da combinação do plano da expressão, de vários elementos e várias semióticas diferentes, mas que recobrem uma totalidade de significação".

Nesse contexto, as imagens utilizadas na composição dos anúncios publicitários não podem ser consideradas meramente ilustrativas, visto que

\footnotetext{
${ }^{6}$ Marcuschi define suporte como "um locus físico ou virtual com formato específico que serve de base ou ambiente de fixação do gênero materializado como texto. Pode-se dizer que suporte de
}

produzem sentido e exercem papel importante no gerenciamento da atenção e na manipulação do destinatário. A propósito, Hernandes (2005) aponta que há décadas pesquisadores, teóricos, jornalistas e publicitários travam discussões acerca do que é mais ou menos importante, persuasivo, sedutor nos textos dessa natureza: se o "verbal" ou o "visual". No entanto, de acordo com o autor, tais discussões são inúteis, uma vez que, "em mídia, é quase impossível encontrar um cartaz, ou comercial de TV, um outdoor que utilize uma única linguagem. Até em um simples spot de rádio, no qual alguém só fala, trabalha-se com a entonação de voz." (HERNANDES, 2005, p. 228). Nessa perspectiva, é preciso considerar que imagens são grandezas semióticas constituídas por elementos de outros sistemas semióticos (cores, formas, gestualidade, etc.) que também possuem significação e que, como constituintes do arranjo sincrético, estão a serviço da construção dos sentidos do enunciado como um todo.

A publicidade é leve e sedutora. Segundo Carvalho (2009), ela não tem autoridade para ordenar, então utiliza uma manipulação disfarçada, sem deixar transparecer suas verdadeiras intenções, com vistas a convencer e seduzir o receptor. Os anúncios publicitários criam um mundo ideal, com encanto, beleza perfeita e não perecível, longe de tudo que possa ser triste. A mensagem concilia o princípio do prazer com a realidade, indicando o que deve ser usado ou comprado, destacando a linguagem da marca ou o ícone do objeto. O papel da publicidade é tornar familiar o produto e, ao mesmo tempo, valorizálo com diferenciação.

Os gêneros desse domínio podem ser veiculados em diferentes suportes ${ }^{6}$ (cartazes, folhetos, placas, outdoors, luminosos, TV, rádio, etc.). O anúncio publicitário objeto de estudo é veiculado num suporte do tipo outdoor, que, de acordo com Carvalho (2009, p. 16), é um

cartaz de grandes proporções posicionado em locais estratégicos, de modo a ser visto por um grande número de pessoas que passam de

um gênero é uma superfície física em formato específico que suporta, fixa e mostra um texto". (2008, p. 174, grifos do autor). 
carro, de ônibus ou mesmo a pé, faz parte da máquina de criar desejos e transformá-los em necessidades. Utiliza mensagens curtas e diretas associadas a imagens igualmente simples e fortes para convencer as pessoas a respeito de uma idéia ou produto.

Por ser um texto sincrético, devemos ler a mensagem considerando o enunciado como um todo, o que implica compreender as relações semânticas que se estabelecem entre os elementos verbais e não verbais presentes no anúncio e que fazem dele um texto único. Os elementos desses arranjos são empregados (e trabalhados) numa perspectiva estética com vistas à adesão/sedução do leitor e implicam percepções, implícitos e relações subconscientes. Como explica Hernandes (2005, p. 228),

em uma publicidade, encontramos geralmente um tipo de texto sincrético cujo plano de expressão é riquíssimo. Seu uso privilegia não o aspecto utilitário, mas o estético, a busca de efeitos de beleza, de estranhamento, entre outros. Entra aí não só a questão do inteligível (do que é racional), mas principalmente a do sensível.

Assim, os arranjos publicitários têm o poder de transformar um relógio em joia, uma casa em castelo, já que, como argumenta Carvalho (2009, p. 18), "a palavra deixa de ser meramente informativa, e é escolhida em função de sua força persuasiva, clara ou dissimulada. Seu poder não é simplesmente o de vender tal ou qual marca, mas integrar o receptor à sociedade de consumo". Complementamos que não só a palavra, mas todos os elementos significantes que entram na constituição desses arranjos são trabalhados numa perspectiva estética.

Dentre as principais características da linguagem verbal empregada nos anúncios publicitários estão a utilização de frases curtas e de efeito, as metáforas, as rimas e os verbos no imperativo. Na linguagem não verbal, comumente se utilizam imagens que representam de forma icônica o produto e/ou a marca anunciados (por exemplo, um anúncio de automóvel em que o veículo aparece no arranjo), ou que associam a eles (ao produto e à marca) uma ideia, um valor tido como desejável pelo leitor (propagandas de seguro de banco costumam associar imagens de famílias felizes, em momentos de lazer, ao produto ofertado). Assim, as imagens trazem mensagens implícitas que não poderiam ser projetadas com palavras em determinados gêneros e/ou suportes.

\section{Análise do anúncio publicitário da Femaçã 2015}

É rotineiro nos depararmos com anúncios publicitários espalhados pelas cidades para divulgar festas, eventos ou feiras. Foi um desses anúncios que fez com que a Femaçã 2015 se tornasse motivo de debates nas redes sociais e meios de comunicação. Muitas feiras comerciais acontecem na região do evento (Serra Gaúcha) e, em todas elas, são escolhidas soberanas (rainha ou imperatriz e princesas) para representarem o evento e o município. A escolha das mulheres varia conforme as cidades, mas os júris normalmente levam em consideração a beleza, a simpatia e o carisma das candidatas. Após eleitas, costumeiramente, as soberanas passam a ser vistas em diversos meios de divulgação usando vestidos, coroas e penteados que lembram verdadeiras rainhas e princesas.

Nesse sentido, o anúncio de divulgação da Femaçã 2015 causa estranhamento, em primeiro plano, pelo traje típico das soberanas, ou melhor, pela falta dele. A publicidade veiculada no outdoor é a seguinte: 


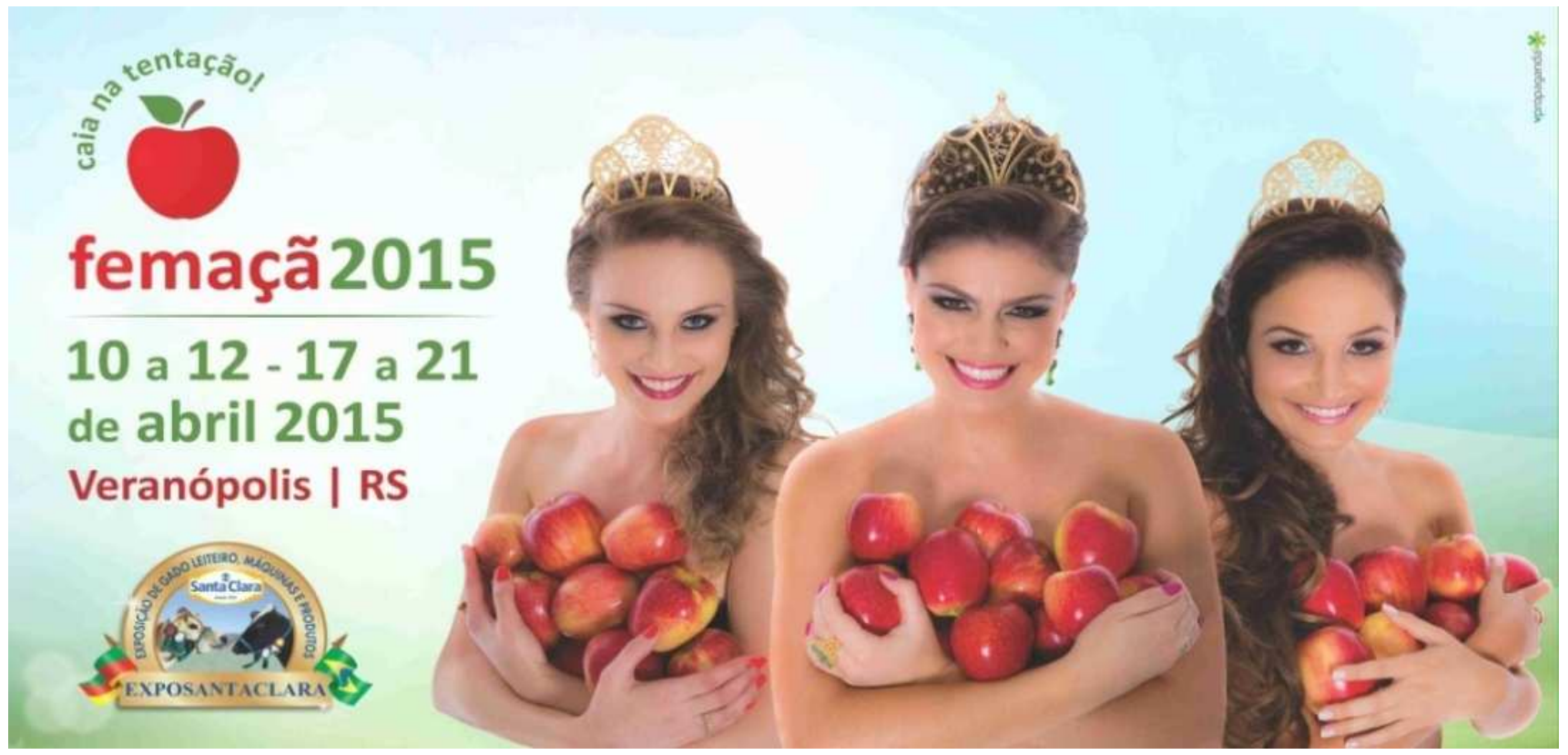

Fonte: Femaçã, 2015.

Como se vê, trata-se de um texto sincrético de natureza estética, uma vez que, como explica Hernandes (2005), diferentes elementos são mobilizados e trabalhados para a construção de um sentido que não é meramente informativo. O conteúdo veiculado evoca outros discursos com os quais dialoga de forma interdiscursiva - entendida essa interdiscursividade como mecanismo implícito e inerente aos enunciados, na perspectiva de Bakhtin (2003) e Fiorin (2006a) - e também de forma intertextual, trazendo elementos materiais que remetem explicitamente a um outro texto anterior (FIORIN, 2006a). Nesse sentido, vamos nos ater aos principais elementos que, projetados no texto, remetem a discursos outros que intervêm na construção do sentido. Importam-nos as relações semânticas que se estabelecem entre os elementos do enunciado, bem como entre o enunciado e os discursos com que ele dialoga.

Começamos com a imagem das soberanas. A imagem das três soberanas seminuas, vestidas apenas com as respectivas coroas e maçãs a lhes cobrirem os seios, retratadas com postura e olhares insinuantes, foge dos padrões usuais utilizados em anúncios similares e remete a interdiscursos de apelo sexual cristalizados na memória do leitor. Não raras publicidades de lingerie e de cerveja, por exemplo, exploram imagens femininas nessa mesma perspectiva (bem maquiadas, corpo à mostra, olhares provocantes, postura sensual). Nesse contexto, o anúncio dialoga com outros discursos que tomam a mulher como objeto sexual, a exemplo do discurso machista da mulher-objeto, estabelecendo com estes uma relação interdiscursiva (BAKHTIN, 2003; FIORIN, 2006a) que causa estranhamento ao público. Surge, também, uma espécie de "inadequação" temática por conta de elementos que evocam o tema da sexualidade na divulgação de uma feira de agroindústria. Ou seja, esse discurso não vem à mente relacionado aos produtos da feira, mas sim às mulheres que ali estão representando o evento.

Aliado a isso, as maçãs vermelhas e o slogan "caia na tentação!" remetem, explicitamente, ao discurso bíblico sobre o pecado original, quando Adão e Eva "caíram em tentação" e comeram o fruto proibido. Consolida-se, então, entre estes dois textos, uma relação intertextual que, como explica Fiorin (2006a), sempre implica uma relação interdiscursiva. A Bíblia (2005, p.16) não faz menção explícita à maça como sendo tal fruta:

A serpente era o mais astuto de todos os animais do campo que Javé Deus havia feito. Ela disse para a mulher: "É verdade que Deus disse que vocês não devem comer de 
nenhuma árvore do jardim? " A mulher respondeu para a serpente: "Nós podemos comer dos frutos das árvores do jardim. Mas do fruto da árvore que está no meio do jardim, Deus disse: 'Vocês não comerão dele, nem o tocarão, do contrário vocês vão morrer".

No entanto, conceber a maçã como sendo o fruto proibido faz parte da cultura popular, do imaginário construído na mente das pessoas. Muitos quadros e afrescos retratam Adão e Eva segurando uma maçã. À vista disso, as três soberanas seminuas, segurando maçãs apetitosas, lembram Eva, que vivia nua no Jardim do Éden até provar do fruto proibido. As cores do pano de fundo do anúncio reforçam isso. A cor verde clara, ao pé da imagem, vai gradativamente mesclando-se ao azul claro logo acima, projetando a ideia de uma planície verdejante sob um céu límpido, de tranquilidade e harmonia ${ }^{7}$, constrói-se, então, um cenário que lembra o "paraíso".

A maçã simboliza a tentação, a escolha errada que proporciona a liberdade e, ao mesmo tempo, o cessar dos privilégios da vida no paraíso. No entanto, como coloca Silva (2016), "a religião predominante aproveitou-se deste fato para apresentar o sexo como o pecado original simbolizado na maçã". Nesse sentido, a relação entre os elementos não verbais do anúncio e o slogan da feira — "caia na tentação! " reportam tanto ao discurso bíblico do pecado original quanto ao da sexualidade tida como sedução e tentação. A propósito, é comum se ouvir a palavra "tentação" aplicada como forma de descrever uma mulher bonita, símbolo de desejo sexual. Assim, o slogan "caia na tentação! " pode fazer referência tanto às maçãs - como frutas tentadoras e apetitosas quanto às mulheres ali retratadas de forma provocante, reforçando o interdiscurso de ordem sexual. Ao mesmo tempo, se apenas as mulheres seminuas aparecessem no anúncio, convidando para um evento qualquer, a relação intertextual com o texto bíblico não ocorreria, já que as maçãs e a frase utilizada no slogan são os principais elementos que permitem estabelecer tal intertextualidade. Por outro lado, continuariam se

\footnotetext{
$7 \mathrm{Na}$ simbologia das cores, o verde é geralmente associado à natureza, à vitalidade, à saúde, à liberdade (GUIMARÃES, 2000). O azul claro simboliza serenidade, tranquilidade e harmonia. Farina, Perez e Bastos (2006, p. 102) apontam que "o céu é azul
}

estabelecendo relações interdiscursivas com outros textos que tomam a mulher como símbolo e objeto sexual.

Também na literatura histórias utilizam a maçã como fruto símbolo do mal. A história infantil da "Branca de Neve e os sete anões" é, provavelmente, a mais conhecida de todas. Nela, a fruta aparece com destaque, pois é o fruto enfeitiçado oferecido à Branca de Neve, que cai no sono e só desperta com o beijo do príncipe. Mais uma vez a maçã é tomada como fruto proibido, que desperta à vontade por sua aparência extremamente apetitosa, mas que não deveria ser provada sob pena de desencadear consequências negativas. Subjaz aí o interdiscurso religioso.

Assim, os elementos verbais e não verbais acionados na construção desse anúncio ativam outros discursos na memória do leitor. As relações dialógicas/interdiscursivas que se estabelecem desencadeiam o caráter polêmico da publicidade e, como explica Hernandes (2005), a polêmica é uma das estratégias publicitárias para vender o produto. Nesse sentido, logo que foi apresentada, a peça publicitária provocou estranhamento, elogios e também diversas críticas. Tais reações configuram-se como atitudes responsivas que, relembrando o que postula Bakhtin (2003), trazem em si juízos de valor atrelados a concepções subjetivas. O Jornal Pioneiro (2015), em sua versão on-line, fez uma enquete com a pergunta "O que você achou do cartaz da Femaçã?". Muitas pessoas consideraram o cartaz vulgar por recorrer à imagem de três mulheres aparentemente nuas, lembrando um "topless". As críticas ainda apontam o machismo e o desrespeito com as mulheres ao utilizálas de forma sensual para atrair o público. Outro jornal on-line, o Diário de Canoas (2015), relata que uma das críticas definiu a publicidade como "propaganda de boate, não de feira".

Em contrapartida, o anúncio também recebeu elogios pela ousadia. Comentários na enquete feita pelo Pioneiro parabenizaram os responsáveis pela divulgação da feira, pois com poucos elementos

e por isso é a cor do divino, a cor do eterno. A experiência continuada converteu a cor azul na cor de tudo que desejamos que permaneça, de tudo que deve durar eternamente". 
conseguiram gerar polêmica e alcançar o objetivo principal: atrair o público. Eduardo Coelho, leitor do jornal, faz menção explícita a Adão e Eva em seu comentário:

Nota 10 para os marketeiros e publicitários da Femaçã. Desde Adão e Eva a "tentação" está ligada à maçã. Além do mais, souberam transmitir a proposta da feira e enaltecer ainda mais a beleza das suas soberanas, de forma respeitosa e profissional. Na tradição pioneira da colonização italiana na serra, alguém sempre deu o primeiro passo. Dessa vez Veranópolis saiu na frente. Parabéns ao povo veranense e à Femaçã! Sucesso absoluto! Caxias do Sul - RS - Brasil 28/01/2015 (PIONEIRO, 2015).

Tal como identificamos na análise, os comentários dos leitores ratificam que 0 estranhamento causado pelo anúncio é decorrente das relações dialógicas - interdiscursivas e intertextuais - que se constroem entre este e outros enunciados/discursos. Os elementos presentes no texto permitem estabelecer essas relações semânticas. As maçãs e o slogan (caia na tentação!) projetam relações intertextuais (FIORIN, 2006a) que fazem alusão direta ao texto bíblico do pecado original, como percebeu o leitor Eduardo Coelho. O slogan, o corpo à mostra, a postura e o olhar provocantes das soberanas estabelecem relações interdiscursivas (BAKHTIN, 2003; FIORIN, 2006a) com outros enunciados (não um em específico) que exploram a mulher como objeto sexual, como percebeu o leitor que definiu o anúncio como "propaganda de boate, não de feira", ou os que relacionaram a publicidade com discursos desrespeitosos e machistas.

\section{Enfim}

Com o estudo proposto, esperamos ter conseguido demonstrar que o sentido do texto em foco - e não só deste - decorre não apenas dos elementos que o constituem, mas das relações dialógicas que se estabelecem com discursos outros internalizados pelo leitor, como propõe Bakhtin (2003). Reiteramos, então, que o estranhamento provocado pelo anúncio da Femaçã 2015 está relacionado aos discursos subjacentes evocados pelo texto: o do pecado original e, principalmente, o da mulher como objeto sexual. Os elementos que se entrelaçam na constituição deste arranjo sincrético, em especial os ora abordados - slogan, maçãs, mulheres seminuas, gestualidade insinuante, pano de fundo - remetem a esses discursos, os quais intervêm diretamente na construção dos sentidos.

Por óbvio, os discursos subjacentes também influenciam na atitude responsiva dos enunciados, sempre atrelada a um juízo de valor. Assim, o anúncio suscita respostas divergentes, associadas a juízos de valor subjetivos e particulares, o que fica claro nos comentários dos leitores. Alguns deles aderem ao enunciado, elogiando-o; outros o refutam, criticando-o. Aliás, o simples estranhamento é, por si só, uma atitude responsiva, uma reação desencadeada pela leitura do arranjo.

Os comentários dos leitores à enquete feita pelo jornal Pioneiro evidenciam, entretanto, que os posicionamentos críticos estão menos associados à relação do texto com o discurso do pecado original e mais com 0 da mulher objeto. Nesse sentido, arriscamos dizer que, talvez, e tão somente talvez, se as soberanas estivessem trajando vestidos típicos, com posturas menos insinuantes, essa última relação interdiscursiva não se estabelecesse. Mas também é possível que, assim, o anúncio não surtisse tanto efeito. Do modo como está construído, o anúncio vende não só o produto ofertado - a maçã - mas, principalmente, a ideia de beleza, de sensualidade, de desejo, de prazer. Tudo isso associado a uma feira de agroindústria.

Em entrevistas concedidas aos meios eletrônicos, os divulgadores da Femaçã afirmaram estar cientes de que a imagem causaria estranhamento e polêmica e que, com isso, buscavam atrair a participação do público para a feira. Isso confirma o que diz Hernandes (2005) sobre as estratégias publicitárias buscarem o estranhamento, o despertar de percepções e relações subconscientes que mexem, de alguma forma, com o leitor, despertando-o para efeitos da ordem do sensível. E, nesse quesito, a publicidade parece ter alcançado o êxito esperado. 


\section{Referências}

AUTHIER-REVUZ, Jaqueline. Hétérogénéitémontréeethétérogénéitéconstitutive: élémentspour une approche de láutredans Le discours. DRLAV, 26, 1982, p. 91-151.

BAHTIA, Vijay K. Análise de gêneros hoje. Rev. de Letras, n. 23,vol. 1/2, p. 102-115 jan/dez. 2001. [Tradução Benedito Gomes Bezerra].

BAKHTIN, Mikhail Mikhailovitch. Estética da criação verbal. 2.ed. São Paulo: Martins Fontes, 2003.

BARROS, Diana Luz Pessoa de. Texto e imagem. Linguagens, n. 1. Porto Alegre, 1986.

Teoria Semiótica do Texto.4.ed. São Paulo: Ática, 2000.

BARTHES, Roland. Novos ensaios críticos. O zero grau da escritura. São Paulo: Cultrix, 1974.

BÍBLIA. Português. Bíblia Sagrada: Edição Pastoral. Tradução: Ivo Storniolo, Euclides Martins Balancin. São Paulo: Paulus, 2005.

CARTAZ de divulgação da Femaçã 2015. V Produtora. Veranópolis, 2015. Disponível em: <http://www.vpropaganda.net/\#portfolio>. Acesso em: 12 fev. 2016.

CARTAZ ousado da Femaçã 2015 gera polêmica na Serra gaúcha. Diário de Canoas, 28 jan. 2015. Disponível em:

$<$ http://www.diariodecanoas.com.br/index.php?id=/noti cias/rio grande do sul/materia.php\&cd matia $=12$ 3606>. Acesso em: 04 fev. 2016.

CARVALHO, Nelly de. Publicidade: a linguagem da sedução. 3. ed. São Paulo: Ática, 2000.

FARINA, Modesto; PEREZ, Clotilde; BASTOS, Dorinho. Psicodinâmica das cores em comunicação. 5. ed. São Paulo: Edgard Blücher, 2006.
FIORIN, José Luiz. Elementos de análise do discurso. 9.ed. São Paulo: Contexto, 2000.

Introdução ao pensamento de Bakhtin. São Paulo: Ática, 2006a.

Interdiscursividade e intertextualidade. In: BRAITH, Beth (Org.). Bakhtin: outros conceitoschave. São Paulo: Contexto, 2006b. p. 161 - 194.

GREIMAS, Algirdas Julien; COURTÉS, Joseph. Dicionário de Semiótica. São Paulo: Contexto, 2008.

GUIMARÃES, Luciano. A cor como informação: a construção biofísica, lingüística e cultural da simbologia das cores. São Paulo: Annablume, 2000.

HERNANDES, Nilton. Duelo: a publicidade da tartaruga da Brahma na Copa do Mundo. In.: LOPES, Ivã; HERNANDES, Nilton (Orgs.) Semiótica: objeto e práticas. São Paulo: Contexto, 2005, p. 227-244.

$\mathrm{KOCH}$, Ingedore Villaça. Intertextualidade e polifonia: um só fenômeno? Revista D.E.L.T.A, n.7, v. 2, p. 529-543, 1991.

$\mathrm{KOCH}$, Ingedore; ELIAS Vanda Maria. Ler e escrever. estratégias de produção textual. 2. ed. São Paulo: Contexto, 2011.

MARCUSCHI, Luiz Antônio. Produção textual, análise de gêneros e compreensão. São Paulo: Parábola, 2008.

O QUE você achou do cartaz da Femaçã? Jornal Pioneiro. Disponível em: <http://pioneiro.clicrbs.com.br/rs/mural/o-que-voceachou-do-cartaz-da-femaca-174350.html> Acesso em: 30 jul. 2015.

SILVA, Ezequiel. É a maçã o fruto do pecado? Jornal Seara News. Disponível em: $<$ http://www.searanews.com.br/e-a-maca-o-frutodo-pecado/>. Acesso em 03 fev. 2016.

\section{COMO CITAR ESSE ARTIGO}

CRESTANI, Luciana Maria; BOFF, Josiane. Relações dialógicas e produção de sentidos: análise do anúncio publicitário da Femaçã 2015. Signo, Santa Cruz do Sul, v. 41, n. 71, set. 2016. ISSN 1982-2014. Disponível em: <https://online.unisc.br/seer/index.php/signo/article/view/7134>. Acesso em: http://dx.doi.org/10.17058/signo.v41i71.7134. 